\title{
Exploring the changes in risk perceptions and adaptation behaviors based on various socioeconomic characteristics before and after earthquake disasters - a case study in Taiwan
}

\author{
Tzu-Ling Chen ${ }^{1}$, Tzu-Yuan Chao ${ }^{2}$, and Hao-Teng Cheng ${ }^{2}$ \\ ${ }^{1}$ Department of Urban Development, University of Taipei, Taipei City, 111, Taiwan \\ ${ }^{2}$ Department of Urban Planning, National Cheng Kung University, Tainan City, 701, Taiwan
}

Correspondence: Tzu-Ling Chen (skylight@mail2000.com.tw)

Received: 23 December 2019 - Discussion started: 3 March 2020

Revised: 2 July 2020 - Accepted: 28 July 2020 - Published: 15 September 2020

\begin{abstract}
Resilience, which has rapidly become an area of interest in multiple disciplines, is regarded as being key in disaster mitigation and adaptation. The objective-indicator framework is a common way to evaluate resilience, but limited attention has been paid to measuring the risk perceptions and adaptation behaviors of individuals. In addition, due to limitations related to predicting potential earthquake events, past studies have placed more emphasis on predisaster discussions. Fortunately, this paper explores the changes in risk perceptions and adaptation behaviors in different socioeconomic groups through a comparative analysis between preand postearthquake disasters and through one-way analysis of variance (ANOVA) with a post hoc test applied to examine the changes in risk perceptions and adaptation behaviors. The results show that people tend to have greater risk perceptions of future earthquakes but are less willing to retrofit their houses after a serious disaster. Females show greater fear and worry accompanied by a higher willingness to retrofit their houses compared to males. In addition, people with a higher education level and a better occupation might be more willing than others to adopt adaptation behaviors. The results can serve as a reference to provide risk communication, risk education, and diverse disaster adaptation options. Although limitations exist, the results of comparative analysis between the predisaster and postdisaster conditions could serve as a reference for adequate strategies and government decisions on the prioritization of risk management policies.
\end{abstract}

\section{Introduction}

The Ring of Fire in East Asia has been regarded as the region most frequently hit by earthquake disasters because of the high rate of earthquakes that have previously occurred there compared to the global rate (USGS, 2017). The call for disaster prevention and risk reduction has been made since the declaration of the International Decade for Natural Disaster Reduction in 1999 (UNISDR, 1999). To mitigate dramatic losses, governments have invested a great number of public resources to finance disaster management, and in particular, structural engineering measures are a major approach taken to cope with earthquake events. However, the risk of property damage and loss of life is possible wherever development is allowed in potentially seismic areas because the occurrence of disasters may be at or below the design standard incorporated into building codes and structural work areas (Kerr et al., 2003; Petak and Atkisson, 1982; Sheaffer and Roland, 1976). The disadvantage of the common reliance on structural engineering measurements has resulted in a new research focus on mediating the exposure to risk by selecting suitable adjustments. Recently, the Sendai Framework for Disaster Risk Reduction 2015-2030 has stipulated that the main priorities for disaster mitigation and adaptation are minimizing disaster risk and building resilience (UNISDR, 2019).

It is necessary to minimize disaster risk and build resilience by self-evaluating the capabilities and capacities in responding to risk, that is, preparedness (Jones and Tanner, 2017). Being prepared for future disaster requires various components, such as sufficient individual characteris- 
tics, social connections, and financial affordability (Baker and Cormier, 2015). People who are included in vulnerable minority groups and marginalized people might not be able to prepare in advance (Blake et al., 2017). Therefore, an increasing number of studies have emphasized measuring risk perceptions at the individual and household levels (Brown and Westaway, 2011; Adger et al., 2009). The perception of disaster risk does not represent a direct function of the probability that threatening events will occur; rather, risk perception captures many other factors, such as attitude, cognition, the degree of danger comprehension, and vulnerability (Sjöberg, 1996, 2000; Eagly and Chaiken, 1993). Despite the substantial literature illustrating the origin (Barrows, 1923), concept (Sjöberg, 2000, 1996), formation (Lindell et al., 2016; Whitney et al., 2004; Wu and Lindell, 2004; Lindell and Perry, 2000), and physical and social contexts of disaster risk perceptions (Blanchard-Boehm and Cook, 2004; Peacock et al., 2003, 2005), less attention has been paid to systematically examining changes in risk perceptions.

In fact, disaster experiences might facilitate or constrain preparedness (Becker et al., 2017; Ejeta et al., 2015; Lindell and Perry, 2011; Bostrom, 2008), and such effects might be biased across disasters, cultures, or regions. A disaster resulting in limited impacts or the assumption that a future disaster will not occur might encourage people to not prepare for future disasters (Paton et al., 2014; Barron and Leider, 2010). Alternatively, people might take any adaptation approaches based upon damage or losses, physical injury, emotional injury and so on (Perry and Lindell, 2008; Nguyen et al., 2006; Heller et al., 2005). The physical damage or losses (Solberg et al., 2010) and psychological fear or anxiety (Rüstemli and Karanci, 1999) resulting from disaster experiences could motivate adaptation behaviors. However, socioeconomic characteristics such as income, age, and gender might encourage or discourage individuals from taking adaptive actions (Bankoff, 2006; Wisner et al., 2004). For example, if people cannot act adequately to mitigate such anxiety, they might take no actions at all (Paton and McClure, 2013). Due to limited knowledge and resources, people tend not to respond to common disasters and tend to have personal preferences for disasters, such as denying disasters, denying the probability of disaster, and having certain beliefs about the government and public infrastructure. Therefore, examining risk perceptions and adaptation behaviors based on various socioeconomic characteristics could provide important information for disaster management.

In summary, the threats in a given area posed by future earthquakes with a magnitude larger than that experienced in the past create uncertainty in regard to the ability to mitigate impacts to acceptable levels using only engineering or construction measures. Humans have the capacity to respond to the environment to reduce risk by learning from past experience, and changes in attitudes and behaviors are very helpful in responding to earthquake disasters (Gifford, 2014). Theoretically, a more accurate measurement and tracking of the interactions of socioeconomic characteristics that collectively affect responses to disasters might help support the right activities and target the right people in disaster management (Oddsdottir et al., 2013; Adger, 2000). Past studies have placed more emphasis on predisaster conditions to explore the interaction effects of various socioeconomic characteristics on individuals' decisions (Levine, 2014). Examining predisaster and postdisaster conditions could reveal the impact of extreme events and how people's perceptions of such events and their willingness to take potential adaptation approaches might change. Therefore, this study contributes to exploring how earthquake disasters influence the risk perceptions and adaptation behaviors of residents in Taiwan and further categorizes them according to socioeconomic characteristics. The sample is of particular interest because it contains pre- and postdisaster information on residents who were directly affected by the Meinong earthquake (participants completed surveys approximately 1 year before and 3 months after the earthquake), allowing for a more robust analysis of the effects of natural disasters on subjective resilience compared to previous research. Based on past studies, the interactions of socioeconomic characteristics can collectively affect responses to disasters. This study discusses such responses based on various socioeconomic characteristics to explore how such characteristics affect pre- and postearthquake risk perceptions and adaptation behaviors. In addition to the introduction, this paper is organized as follows. Section 2 provides a brief description of the research design, including the study area, the data collection, the measures for subjective resilience, and the methods. Section 3 presents the comparative analysis between pre- and postdisaster surveys based on the results of one-way analysis of variance (ANOVA). Section 4 presents the comparative analysis between our findings and those of past studies. The final section offers some conclusions.

\section{Data and methodology}

\subsection{Study area}

The study area of Taiwan is located along the Philippine Sea Plate and the Eurasian Plate, and the orogenic belt of central-southern Taiwan has undergone intensive crustal deformation. It is exposed to earthquake events, as most active faults were confirmed after the city had already been built on them. An active fault called the Houchiali Fault trends north to south across the study area (Lin et al., 2000; Chen and Liu, 2000). Although the existing Houchiali Fault has recently been identified as a Late Pleistocene active fault, an intensified and densely built environment has developed right on and close to the fault line (see Fig. 1b). In addition, there is increasing population growth in the study area, and in particular, some areas along the fault line have a relatively densely clustered population (see Fig. 1c, d). In ad- 
dition, the soft soil might amplify surface ground motion. In 2015, the Meinong earthquake, a local magnitude 6.6 earthquake, struck southern Taiwan, having a devastating impact and resulting in 117 deaths; additionally, numerous buildings were reported to have collapsed (National Applied Research Laboratories, 2018; Tsai et al., 2017). Previously unspecified regulations resulted in a number of five-story buildings without earthquake safety. In the study area of Yongkang, 744 buildings were reported as having been damaged and, in particular, one building fully collapsed, resulting in 115 deaths (see Fig. 1a). According to the Central Weather Bureau (Huang et al., 2009), a large-magnitude earthquake occurs once every 30 years in southern Taiwan. A low willingness to make repairs was found, even though the government encourages inhabitants with this low willingness to retrofit buildings through subsidies and tax relief. The Statute for Expediting Reconstruction of Urban Unsafe and Old Buildings was quickly promulgated on 10 May 2017.

\subsection{Data collection}

There are 39 townships within the study area. A total of 429 individuals completed the predisaster survey, which was conducted between October and December 2014. The postearthquake follow-up survey was conducted in May 2016 (3 months after the Meinong earthquake), and trained interviewers conducted the survey over the phone, asking the same questions as those in the predisaster survey. All survey sampling methods relied on voluntary-response sampling. The predisaster survey was a street survey, while the postdisaster survey was a telephone survey based on phone number databases within the study area and conducted by the survey research center of a domestic academic institution. The respondents were reminded of some particular information regarding the most recent earthquake, the geographic location of the nearest fault line, the impact of the disaster event, the frequency of earthquakes in the study area, etc. Additionally, the scale of earthquake magnitude is defined as over 6.0. The content of the survey questions contained five parts: behavioral intentions to adopt residential seismic strengthening, risk perceptions, sensitivity to earthquakes, trust in the government, and responsibility attribution. All parts contained at least three items. The main goal of our study is to explore the trajectory of risk perceptions and adaptation behaviors before and after the Meinong earthquake. The same questionnaire allows for us to examine these issues with the same earthquake risk area 1 year before and 3 months after this disaster.

\subsection{Measures for risk perceptions and adaptation behaviors}

Perceived risk is not necessarily equivalent to the probability of occurrence of a disaster. Rather, it summarizes many other factors. Increasing research focuses on the risk perceptions of earthquake disasters, and such perceptions might vary. Previous studies have shown that terror often accompanies changes in the physical environment, the loss of human lives, and the destruction of property. Therefore, among earthquake-related stressors, we were concerned with individuals' perceptions of the probability of an earthquake disaster occurring within 10 years and the impacts they expected from such a disaster, including fear of earthquakes and worries over buildings collapsing.

Although prior disaster experiences and observation of the natural environment might form disaster perceptions, various socioeconomic characteristics might further affect such perceptions. Adaptation behavior is a way for individuals to adapt their living environment to new events that may occur and impact the existing system. People who have faith in adaptation behaviors might take whatever approaches they have available, while others might take no such approaches. Therefore, in the adaptation behavior section, we were concerned with the ways in which people respond to earthquake disasters. To survive earthquakes, seismic restraints might play important roles during such disasters. Hence, there are two items regarding house retrofitting, including the willingness to retrofit houses and house retrofitting after professional assessment.

There are five items in the survey to explore both risk perceptions and adaptation behaviors. Risk perceptions are measured by three items on the expected impacts of earthquakes, and adaptation behaviors are measured by two items on the willingness to support policies. The measurement, shown in Table 1, combines 7-point Likert-scale items and yes-no questions (see Table 1). A transformation process is conducted to solve the problems posed by scales with different measurement systems.

\subsubsection{Methods - one-way analysis of variance}

One-way ANOVA is an extension of the independent sample $t$ test that can be used to compare any number of groups (Bewick et al., 2004; Whitely and Ball, 2002). The core value of one-way ANOVA lies in the ability to examine means that are significantly different from each other between groups. One-way ANOVA is calculated as follows:

$\frac{\sum_{i=1}^{n}\left(x_{i}-\bar{x}\right)^{2}}{n-1}$,

where the variance comes from a set of $n$ values $\left(x_{1}, x_{2}, \ldots, x_{n}\right)$ and the degrees of freedom is $n-1$.

In one-way ANOVA, the $F$-statistic test is used and represented equally among groups. A significant $F$-statistic test 


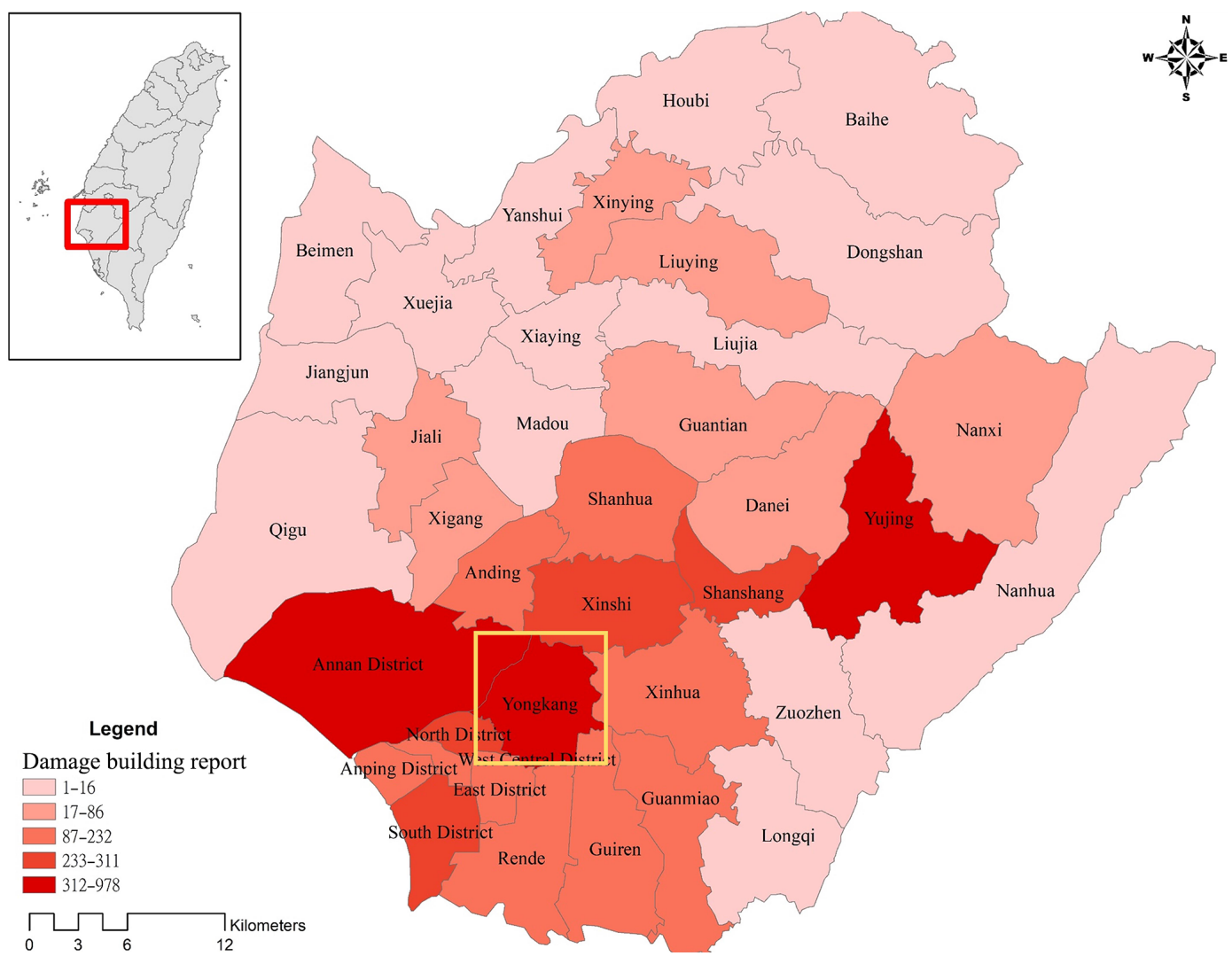

Figure 1. Study area.

Table 1. Measurement of the questionnaires.

\begin{tabular}{llll}
\hline Aspects & Items & Predisaster & Postdisaster \\
\hline Risk perceptions & Probability of an earthquake disaster occurring & 7-point & 7-point \\
& within the next 10 years & & \\
& Fear of earthquakes & 7-point & 7-point \\
& Worries over buildings collapsing & 7-point & 7-point \\
\hline \multirow{2}{*}{ Adaptation behaviors } & Willingness to retrofit houses & Yes-no & 7-point \\
& Willingness to retrofit houses after assessment & Yes-no & 7-point \\
\hline
\end{tabular}

Completely disagree $=1$ to completely agree $=7$.

result indicates a significant difference between groups, and the $p$ value of 0.05 is the common threshold. First, Levene's test is applied to examine the null hypothesis that the variance is equal across groups. A result of Levene's test lower of than 0.05 indicates that it is necessary to apply Welch's test because there is no equal variance between groups. On the other hand, if the result of Levene's test is greater than 0.05 , then we can depend on the ANOVA results. Overall, a significant $F$ statistic in both Welch's test and ANOVA indicates that at least two groups are different, but it does not identify which groups are different from the others. However, a $p$ value lower than 0.05 indicates significance or the probability of a type II error, which is the possibility of in- correctly rejecting the null hypothesis or wrongly concluding a difference between groups. Therefore, a post hoc test and multicomparison analysis testing are necessary to avoid type II errors and to further examine the differences between levels. Due to the assumption of homogeneity of variance, we then apply the Games-Howell test and Benjamini-Hochberg procedure (Fig. 2).

Quantitative data analysis was conducted using the Statistical Package for the Social Sciences (SPSS) software. Each response to the items in the questionnaire survey was rated on a scale ranging from 1 to 7 , with 1 as the highest level of vulnerability (or lowest level of resilience) and 7 as the lowest level of vulnerability (highest level of resilience). 


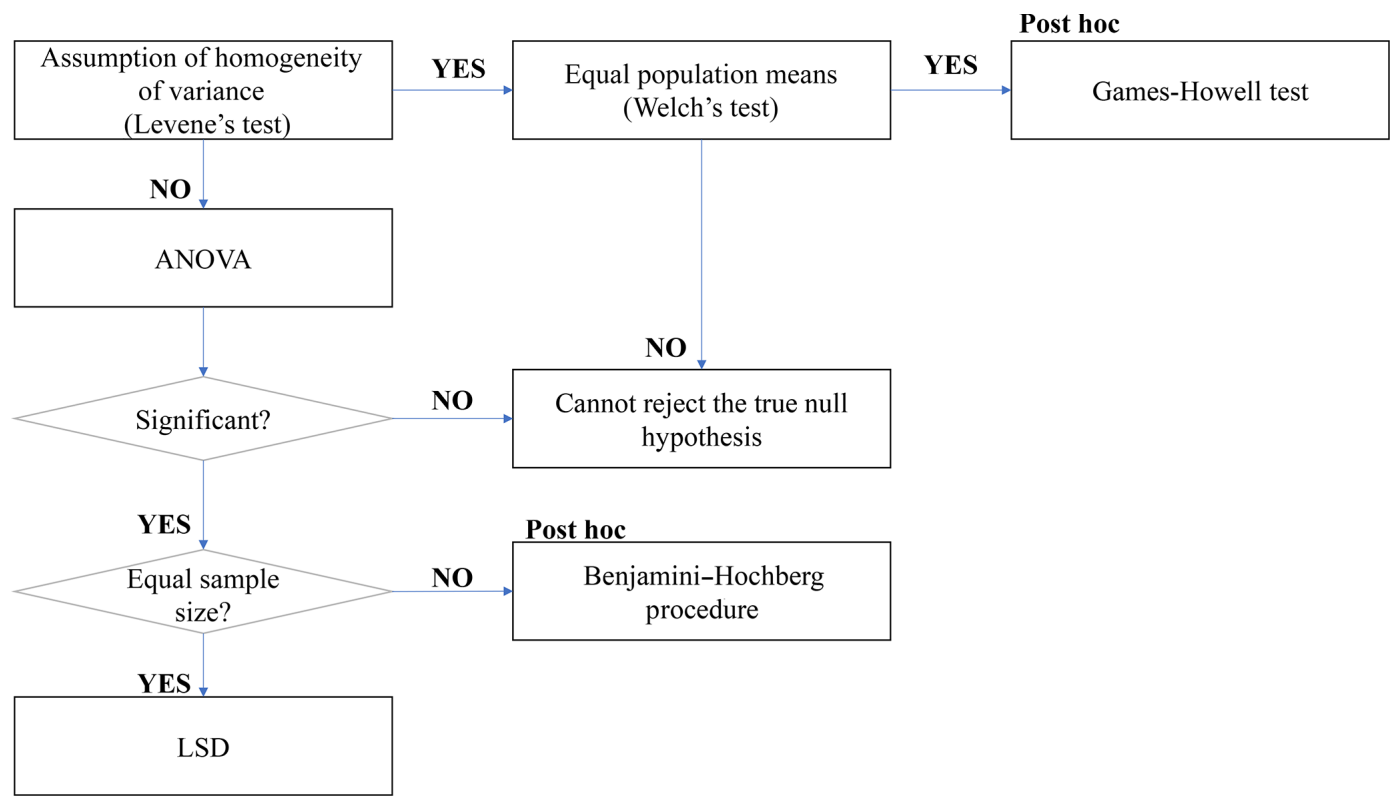

Figure 2. Overall process of one-way analysis of variance.

Table 2. Sample characteristics in the pre- and postearthquake surveys.

\begin{tabular}{|c|c|c|c|c|c|c|c|}
\hline Characteristics & Pre & Post & Study area & Characteristics & Pre & Post & Study area \\
\hline \multicolumn{3}{|c|}{ Gender } & & \multicolumn{3}{|c|}{ Occupation* } & \\
\hline Male & $53.38 \%$ & $44.89 \%$ & $49.27 \%$ & Students & $9.09 \%$ & $7.23 \%$ & $38.53 \%$ \\
\hline Female & $46.42 \%$ & $55.11 \%$ & $50.73 \%$ & Homemakers & $10.96 \%$ & $18.94 \%$ & \\
\hline \multicolumn{3}{|c|}{ Age } & & White-collar workers & $37.76 \%$ & $32.55 \%$ & $59.08 \%$ \\
\hline$<15$ years & $7.46 \%$ & $1.70 \%$ & $13.97 \%$ & Blue-collar workers & $41.96 \%$ & $41.28 \%$ & \\
\hline $15-40$ years & $38.23 \%$ & $28.30 \%$ & $37.96 \%$ & \multicolumn{3}{|c|}{ House ownership* } & \\
\hline 40-60 years & $37.53 \%$ & $51.91 \%$ & $32.16 \%$ & Self-owned & $48.95 \%$ & $63.62 \%$ & $85.93 \%$ \\
\hline$>60$ years & $16.78 \%$ & $18.09 \%$ & $15.91 \%$ & Family-owned & $32.17 \%$ & $32.34 \%$ & $3.20 \%$ \\
\hline \multicolumn{3}{|c|}{ Education } & & Renting & $18.65 \%$ & $4.04 \%$ & $7.82 \%$ \\
\hline Elementary or junior high & $21.68 \%$ & $21.91 \%$ & $21.63 \%$ & & & & \\
\hline High school & $47.32 \%$ & $41.49 \%$ & $30.54 \%$ & & & & \\
\hline University or graduate & $31.00 \%$ & $36.60 \%$ & $46.96 \%$ & & & & \\
\hline
\end{tabular}

Note 1: the values without official statistics are replaced by data from the Tainan municipality. Note 2: the share of illiterate individuals in the study area is $0.87 \%$. Note 3: the official statistics for occupation are categorized into employment and unemployment, and the unemployment percentage is $2.39 \%$. In addition, neither students nor homemakers are included in the labor force. Note 4: the official statistics for house ownership include self-owned, family-owned, renting, and other, and the percentages are $85.93 \%, 3.20 \%, 7.82 \%$, and $3.05 \%$, respectively.

\section{Results}

The number of respondents was similar across genders, which is consistent with the gender ratio in the study area. Regarding age, most respondents in the pre- and postearthquake surveys were between 16 and 60 years old and thus had the knowledge and capacity to develop their self-perceptions and adaptation behaviors. Regarding education, most residents in the study area were university graduates. Because the survey was based on voluntary-response sampling, the results showed that there might be inconsistencies in the education category because most respondents graduated from high school. In terms of occupation, the official statistics exclude students and homemakers from the labor force. In Taiwan, we have only the national statistics of the industry and service census ${ }^{1}$. Therefore, the overall occupation ratio in the study area can be divided into two cat-

\footnotetext{
${ }^{1}$ https://eng.stat.gov.tw/np.asp?CtNode $=1548$, last access: 5 August 2020
} 
egories: employment and unemployment. In Taiwanese culture, owning one's house is preferred over renting. Indeed, the survey shows that less than $20 \%$ of the respondents rent their homes (see Table 2). In general, people became highly aware of earthquakes immediately after the Meinong earthquake, but people were unwilling to retrofit their houses. In the following sections, the study attempts to compare risk perceptions and adaptation behaviors pre- and postdisaster based on socioeconomic characteristics such as gender, age, education, occupation, and house ownership.

\subsection{Gender}

In the preearthquake survey, males showed more worries than females regarding building collapse ( $p$ value $=$ $0.008<0.05)$, while the results for the other items were not statistically significant. In the postearthquake survey, the probability of an earthquake disaster occurring within the next 10 years $(p$ value $=0.049<0.05)$, fear of earthquakes ( $p$ value $=0.000000<0.05)$, and the willingness to retrofit houses $(p$ value $=0.002<0.05)$ were statistically significant, indicating variations between the gender categories. The results show that the Meinong earthquake not only increased awareness of earthquakes but also increased the risk perceptions of females (probability of an earthquake disaster, 4.74 for females $>4.51$ for males; fear of earthquakes, 5.64 for females $>4.75$ for males). Both males and females were less willing to retrofit their houses after this serious earthquake. In summary, although the coefficient of risk perception among males is higher than that among females in the preearthquake survey, the coefficient among males becomes lower than that among females in the postearthquake survey. In addition, there is significant variation between gender categories after the Meinong earthquake, and females show higher risk perceptions and a higher willingness to retrofit their houses than males (see Table 3).

\subsection{Age}

According to the $F$ test, the result for worries over buildings collapsing is statistically significant $(p$ value $=0.045<0.05$ ) in the postearthquake survey (see Table 4). To examine whether there are variations, this study applied the Hochberg test. However, the results of the Hochberg test show that there are no statistically significant differences between age groups. Therefore, the overall results show that there are no significant variations among age categories in both the preand postearthquake surveys. Because there are no variations among age groups, we use the mean value to compare the changes between the pre- and postearthquake surveys. In terms of risk perceptions, people tended to become more aware of earthquakes (probability of an earthquake disaster, 4.04 pre $<4.55$ post; fear of earthquakes, 4.91 pre $<5.02$ post; and worries over buildings collapsing, 4.61 pre $=4.61$ post). Regarding adaptation behaviors, people tended to be- come less willing to retrofit their houses. Therefore, the overall results show that there are no significant variations among age categories in both the pre- and postearthquake surveys. It seems that age does not necessarily affect risk perceptions or adaptation behaviors.

\subsection{Education}

Again, in the preearthquake survey, there are no significant variations among education categories, indicating that different educational-level groups show a similar awareness of the probability of earthquakes and a similar willingness to retrofit their houses. In contrast, the results regarding the probability of an earthquake disaster occurring within 10 years $(p$ value $=0.001<0.05)$, worries over buildings collapsing $(p$ value $=0.046<0.05)$, and willingness to retrofit houses $(p$ value $=0.005<0.05$ ) after assessment are statistically significant, indicating significant differences among educational-level categories (see Table 5). This paper further applies post hoc analysis to compare the differences between categories. The results show that different educational-level categories do indeed have different levels of awareness of the probability of earthquakes and different preferences for house retrofitting. For example, one variation $(-0.579)$ shows that people who graduated from elementary or junior high school might have less awareness than people who graduated from university or graduate school. Meanwhile, another variation $(-0.42)$ shows that people who graduated from elementary or junior high school might be less willing to retrofit their houses (see Table 6). Overall, people tended to become more aware of earthquakes after the Meinong earthquake and less willing to retrofit their houses. Although there are no significant results showing that education matters for risk perceptions and adaptation behaviors, after the Meinong earthquakes, those with a higher educational level seemed to become more aware of the probability of earthquakes and more willing to retrofit their houses.

\subsection{Occupation}

The results show that occupation matters for both risk perceptions and adaptation behaviors in both the preand postearthquake surveys. According to the $F$-statistic test, the results for the items on fear of earthquakes ( $p$ value $=0.004<0.05)$ and worries over buildings collapsing $(p$ value $=0.005<0.05)$ in the preearthquake survey (see Table 7) are statistically significant. The results of the Hochberg test show that homemakers have higher risk perceptions than white-collar workers, blue-collar workers, and students (see Table 8). In the postearthquake survey, the results for the probability of an earthquake disaster occurring within the next 10 years $(p$ value $=0.016<0.05)$, fear of earthquakes ( $p$ value $=0.000142<0.05$ ), worries over buildings collapsing ( $p$ value $=0.018<0.05)$, willingness to retrofit houses $(p$ value $=0.008<0.05)$, and willingness 
Table 3. $p$ values and means for gender. DF denotes degrees of freedom.

\begin{tabular}{lrrrrr|rrrrr}
\hline \multirow{2}{*}{ Items } & \multicolumn{4}{c}{ Preearthquake } & \multicolumn{4}{c}{ Postearthquake } \\
\cline { 2 - 10 } & Male & Female & DF & $F$ & $p$ value & Male & Female & DF & $F$ & $p$ value \\
\hline Probability of an earthquake disaster occurring & 4.03 & 4.05 & 415 & -0.211 & 0.836 & 4.51 & 4.74 & 468 & -1.988 & $0.049^{*}$ \\
within the next 10 years & & & & & & & & & & \\
Fear of earthquakes & 5.04 & 4.85 & 415 & 1.643 & 0.101 & 4.75 & 5.64 & 468 & -6.342 & $0.000^{\mathrm{a}^{* * *}}$ \\
Worries over buildings collapsing & 4.77 & 4.44 & 415 & 2.644 & $0.008^{* *}$ & 4.62 & 5.02 & 468 & -2.539 & $0.011^{*}$ \\
Willingness to retrofit houses & 6.42 & 6.23 & 415 & 1254 & 0.218 & 3.96 & 4.37 & 468 & -3.085 & $0.002^{* *}$ \\
Willingness to retrofit houses after assessment & 6.75 & 6.58 & 415 & 1.485 & 0.123 & 5.46 & 5.53 & 468 & -0.646 & 0.519 \\
\hline
\end{tabular}

${ }^{\mathrm{a}} 0.000000 .{ }^{*} p<0.05 .{ }^{* *} p<0.01$. $^{* * *} p<0.001$.

Table 4. $p$ values and means for age.

\begin{tabular}{|c|c|c|c|c|c|c|c|}
\hline \multirow[t]{2}{*}{ Items } & \multicolumn{7}{|c|}{ Preearthquake } \\
\hline & $<15$ years & $16-40$ years & $41-60$ years & $>61$ years & DF & $F$ & $p$ value \\
\hline $\begin{array}{l}\text { Probability of an earthquake disaster occurring } \\
\text { within the next } 10 \text { years }\end{array}$ & 4.00 & 4.02 & 4.00 & 4.15 & 428 & 0.372 & 0.773 \\
\hline Fear of earthquakes & 4.68 & 4.88 & 5.01 & 5.07 & 428 & 1.135 & 0.334 \\
\hline Worries over buildings collapsing & 4.66 & 4.67 & 4.57 & 4.54 & 428 & 0.248 & 0.863 \\
\hline Willingness to retrofit houses & 6.41 & 6.44 & 6.30 & 6.21 & 428 & 0.463 & 0.708 \\
\hline Willingness to retrofit houses after assessment & 6.50 & 6.61 & 6.72 & 6.83 & 428 & 1.121 & 0.340 \\
\hline \multirow[t]{2}{*}{ Items } & \multicolumn{7}{|c|}{ Postearthquake } \\
\hline & $<15$ years & $16-40$ years & $41-60$ years & $>61$ years & DF & $F$ & $p$ value \\
\hline $\begin{array}{l}\text { Probability of an earthquake disaster occurring } \\
\text { within the next } 10 \text { years }\end{array}$ & 4.38 & 4.69 & 4.67 & 4.45 & 466 & 0.935 & 0.424 \\
\hline Fear of earthquakes & 4.50 & 5.17 & 5.39 & 5.02 & 466 & 1.955 & 0.120 \\
\hline Worries over buildings collapsing & 4.13 & 4.72 & 5.04 & 4.54 & 466 & 2.701 & $0.045^{*}$ \\
\hline Willingness to retrofit houses & 4.88 & 4.26 & 4.20 & 3.98 & 466 & 1.285 & 0.279 \\
\hline Willingness to retrofit houses after assessment & 5.50 & 5.53 & 5.52 & 5.39 & 466 & 0.365 & 0.779 \\
\hline
\end{tabular}

${ }^{*} p<0.05 .{ }^{* *} p<0.01 .{ }^{* * *} p<0.001$.

to retrofit houses after assessment $(p$ value $=0.036<0.05$ ) are all statistically significant, indicating significant differences between occupation categories (see Table 7). The results of the post hoc test show that homemakers have the highest awareness of the risk of earthquakes among all occupation categories. In terms of house retrofitting, there are significant variations between white-collar and blue-collar workers. In summary, after the Meinong earthquake, regardless of occupation, people tended to become more aware of earthquakes but less willing to retrofit their houses. In addition, homemakers are much more aware of earthquake risk than those holding other occupations in both the pre- and postearthquake surveys. Due to their economic status, whitecollar workers tended to be more willing to retrofit their houses after the Meinong earthquake compared to blue-collar workers (Fig. 5).

\subsection{House ownership}

Regarding house ownership, most categories show no statistically significant variations in the pre- and postearthquake surveys (see Table 9). In the postdisaster survey, the $p$ value $(0.009<0.05)$ for the willingness to retrofit houses indicates that at least two house ownership groups have significantly different preferences. This paper further applies the post hoc test to examine the different preferences for house retrofitting (see Table 10). The results show that the family-owned group has a higher willingness to retrofit houses than the self-owned group in the postearthquake survey. Overall, regardless of house ownership category, people tended to become more aware of earthquakes and less willing to retrofit their houses in the postearthquake survey. Although there are no particular variations in risk perceptions among the house ownership categories, people who owned their house still show a higher willingness to retrofit their houses compared to those who rented.

\section{Discussion}

According to the results, after the Meinong earthquake, people tended to have greater risk perceptions regarding future earthquakes but were less willing to retrofit their houses. The 
Table 5. $p$ values and means for education.

\begin{tabular}{|c|c|c|c|c|c|c|}
\hline \multirow[t]{2}{*}{ Items } & \multicolumn{6}{|c|}{ Preearthquake } \\
\hline & $\begin{array}{r}\text { Elementary or } \\
\text { junior high }\end{array}$ & Senior high & $\begin{array}{r}\text { University or } \\
\text { graduate }\end{array}$ & DF & $F$ & $p$ value \\
\hline $\begin{array}{l}\text { Probability of an earthquake disaster occurring } \\
\text { within the next } 10 \text { years }\end{array}$ & 4.17 & 4.00 & 4.00 & 428 & 0.999 & 0.369 \\
\hline Fear of earthquakes & 5.03 & 4.93 & 4.90 & 428 & 0.338 & 0.714 \\
\hline Worries over buildings collapsing & 4.58 & 4.72 & 4.47 & 428 & 1.579 & 0.207 \\
\hline Willingness to retrofit houses & 6.18 & 6.31 & 6.51 & 428 & 1.361 & 0.258 \\
\hline Willingness to retrofit houses after assessment & 6.80 & 6.58 & 6.75 & 428 & 1.889 & 0.152 \\
\hline \multirow[t]{2}{*}{ Items } & \multicolumn{6}{|c|}{ Postearthquake } \\
\hline & $\begin{array}{r}\text { Elementary or } \\
\text { junior high }\end{array}$ & Senior high & $\begin{array}{r}\text { University or } \\
\text { graduate }\end{array}$ & $\mathrm{DF}$ & $F$ & $p$ value \\
\hline $\begin{array}{l}\text { Probability of an earthquake disaster occurring } \\
\text { within the next } 10 \text { years }\end{array}$ & 4.25 & 4.67 & 4.83 & 469 & 7.468 & $0.001^{* *}$ \\
\hline Fear of earthquakes & 5.12 & 5.28 & 5.26 & 469 & 0.402 & 0.669 \\
\hline Worries over buildings collapsing & 4.64 & 5.07 & 4.69 & 469 & 3.100 & $0.046^{*}$ \\
\hline Willingness to retrofit houses & 4.12 & 4.19 & 4.22 & 469 & 0.154 & 0.857 \\
\hline Willingness to retrofit houses after assessment & 5.27 & 5.45 & 5.69 & 469 & 5.342 & $0.005^{* *}$ \\
\hline
\end{tabular}

${ }^{*} p<0.05{ }^{* *} p<0.01 .{ }^{* * *} p<0.001$.

Table 6. Post hoc results for education (for the categories compared across the two education columns).

\begin{tabular}{|c|c|c|c|c|c|c|c|}
\hline \multirow[t]{2}{*}{ Items } & \multirow[t]{2}{*}{ Education 1} & \multirow[t]{2}{*}{ Education 2} & \multirow[t]{2}{*}{ Mean difference } & \multirow[t]{2}{*}{ SE } & \multirow[t]{2}{*}{ Sig. } & \multicolumn{2}{|c|}{$95 \%$ confidence interval } \\
\hline & & & & & & Lower bound & Upper bound \\
\hline \multirow{2}{*}{$\begin{array}{l}\text { Probability of an } \\
\text { earthquake disas- } \\
\text { ter occurring within } \\
\text { the next } 10 \text { years } \\
\text { (postearthquake) } \\
\text { Hochberg test }\end{array}$} & Elementary or junior high & High school & -0.414 & 0.148 & $0.015^{*}$ & -0.77 & -0.06 \\
\hline & Elementary or junior high & University or graduate & -0.579 & 0.151 & $0.000^{* * *}$ & -0.94 & -0.22 \\
\hline $\begin{array}{l}\text { Retrofitting houses af- } \\
\text { ter professional assess- } \\
\text { ment (postearthquake) } \\
\text { Hochberg test }\end{array}$ & Elementary or junior high & University or graduate & -0.420 & 0.133 & $0.005^{* *}$ & -0.74 & -0.10 \\
\hline
\end{tabular}

findings show that people might become less willing to prepare, which is quite similar to the result of a survey conducted after the 2011 Christchurch earthquake (Paton and Johnston, 2008). In fact, the relationship between disaster experience and preparedness has been regarded as a key issue based on the recommendations of the Sendai Framework (UNDRR, 2015). According to past studies, it is difficult for people to imagine any consequences if they lack earthquake experience (Paton and McClure, 2013). However, the study finds that the levels of disaster preparedness become low after serious disasters. Therefore, disaster experience might not necessarily increase people's willingness to prepare. On the other hand, socioeconomic characteristics might still affect the decision-making process with regard to adopting adaptation behaviors.
In terms of gender, females show greater fear and worries regarding future earthquake disasters than males, while they have a similar willingness to retrofit their houses (see Fig. 3). According to past studies, the responses of women might be more internal and backstage, whereas those of men might be more external and front stage (Enarson, 2001; Always et al., 1998; Fordham, 1998). The economic status and family role of women might forbid possible adaptive choices compared to men (Tobin-Gurley and Enarson, 2013). Men, in contrast, are more risk tolerant than women (Finucane et al., 2000). Although gender inequality prevails in different ways around the world, women's safety concerns for their family have been well documented in both environmental-protection movements and neighborhood emergency preparedness campaigns (Litt et al., 2012; Luft, 2008; Erikson, 1994; Turner et 
Table 7. $p$ values and means for occupation.

\begin{tabular}{|c|c|c|c|c|c|c|c|}
\hline \multirow[t]{2}{*}{ Items } & \multicolumn{7}{|c|}{ Preearthquake } \\
\hline & Students & $\begin{array}{l}\text { Home- } \\
\text { makers }\end{array}$ & $\begin{array}{r}\text { White-collar } \\
\text { workers }\end{array}$ & $\begin{array}{r}\text { Blue-collar } \\
\text { workers }\end{array}$ & $\mathrm{DF}$ & $F$ & $p$ value \\
\hline $\begin{array}{l}\text { Probability of an earthquake disaster occurring } \\
\text { within the next } 10 \text { years }\end{array}$ & 4.05 & 3.87 & 4.10 & 4.01 & 427 & 0.654 & 0.581 \\
\hline Fear of earthquakes & 4.69 & 5.49 & 4.81 & 4.97 & 427 & 4.430 & $0.004^{* *}$ \\
\hline Worries over buildings collapsing & 4.28 & 5.19 & 4.52 & 4.61 & 427 & 4.340 & $0.005^{* *}$ \\
\hline Willingness to retrofit houses & 6.41 & 5.68 & 6.39 & 6.46 & 427 & 3.413 & 0.118 \\
\hline Willingness to retrofit houses after assessment & 6.68 & 6.27 & 6.76 & 6.71 & 427 & 2.795 & 0.40 \\
\hline \multirow[t]{2}{*}{ Items } & \multicolumn{7}{|c|}{ Postearthquake } \\
\hline & Students & $\begin{array}{l}\text { Home- } \\
\text { makers }\end{array}$ & $\begin{array}{r}\text { White-collar } \\
\text { workers }\end{array}$ & $\begin{array}{r}\text { Blue-collar } \\
\text { workers }\end{array}$ & $\mathrm{DF}$ & $F$ & $p$ value \\
\hline $\begin{array}{l}\text { Probability of an earthquake disaster occurring } \\
\text { within the next } 10 \text { years }\end{array}$ & 4.35 & 4.82 & 4.80 & 4.47 & 469 & 3.475 & $0.016^{*}$ \\
\hline Fear of earthquakes & 4.47 & 6.04 & 5.16 & 5.06 & 469 & 12.266 & $0.000^{\mathrm{a}^{* * *}}$ \\
\hline Worries over buildings collapsing & 4.26 & 5.25 & 4.88 & 4.72 & 469 & 3.392 & $0.018^{* *}$ \\
\hline Willingness to retrofit houses & 4.32 & 4.34 & 4.41 & 3.91 & 469 & 3.995 & $0.008^{* *}$ \\
\hline Willingness to retrofit houses after assessment & 5.38 & 5.57 & 5.67 & 5.35 & 469 & 2.873 & $0.036^{*}$ \\
\hline
\end{tabular}

a $0.000000 .{ }^{*} p<0.05 .{ }^{* *} p<0.01 .{ }^{* * *} p<0.001$.
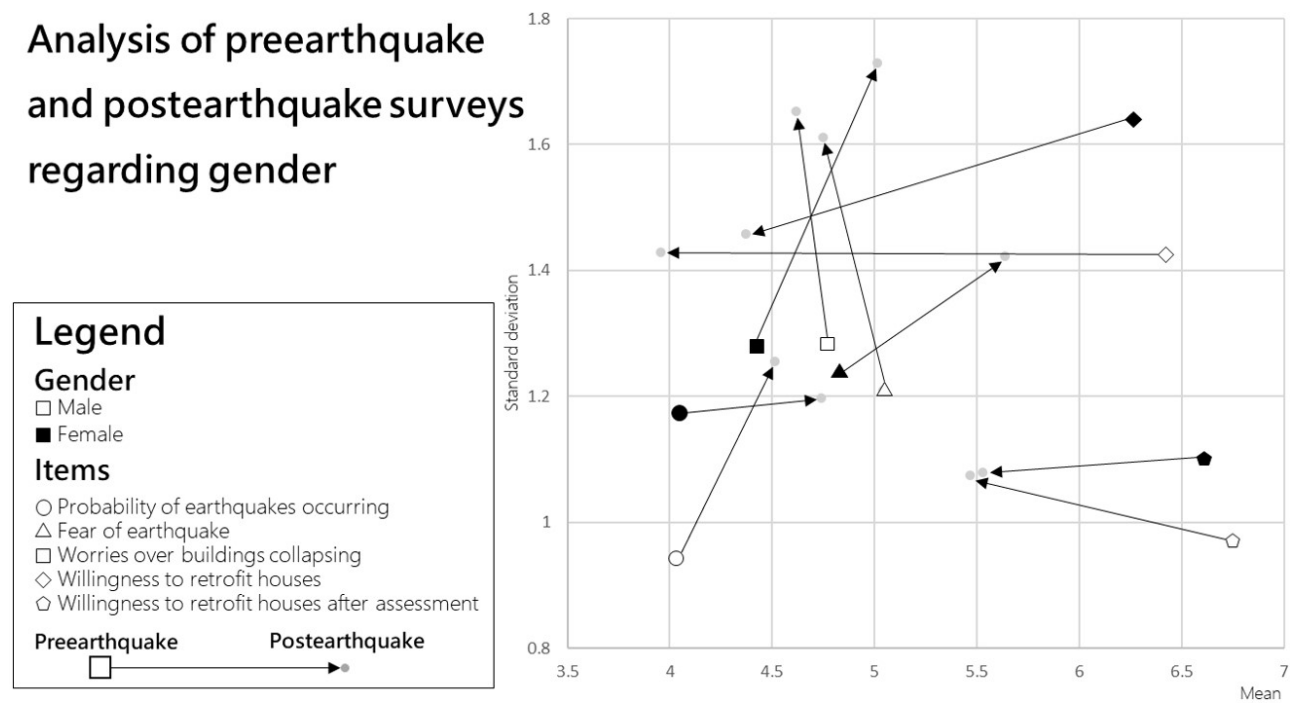

Figure 3. Comparative analysis of the pre- and postearthquake surveys regarding gender.

al., 1986). Therefore, it is necessary to provide more diverse options for house retrofitting for families to increase their potential willingness to improve the antiseismic resilience of their houses.

Regarding education, people tend to become aware of earthquake risk after a serious disaster event, and there are no significant variations between educational-level categories. Although there is a significant decrement in the result for house retrofitting, people who have a university-level education might be more willing to retrofit their houses (see Fig. 4).
There are similarities in occupation; people who are whitecollar workers are still much more willing to retrofit their houses than blue-collar workers, homemakers, and students. In addition, homemakers have higher risk perceptions than those belonging to the other occupation categories. Available resources might be the key factor affecting whether people prepare for and respond to disasters. Social stratification plays a role in perceiving and reacting to risk, including people's understanding of disaster information, the sources an- 
Table 8. Post hoc results for occupation (for the categories compared across the two occupation columns.

\begin{tabular}{|c|c|c|c|c|c|c|c|}
\hline \multirow[t]{2}{*}{ Items } & \multirow[t]{2}{*}{ Occupation 1} & \multirow[t]{2}{*}{ Occupation 2} & \multirow[t]{2}{*}{ Mean difference } & \multirow[t]{2}{*}{ SE } & \multirow[t]{2}{*}{ Sig. } & \multicolumn{2}{|c|}{$95 \%$ confidence interval } \\
\hline & & & & & & Lower bound & Upper bound \\
\hline \multirow{3}{*}{$\begin{array}{l}\text { Fear of earthquakes } \\
\text { (preearthquake) } \\
\text { Hochberg test }\end{array}$} & Students & Homemakers & -0.797 & 0.263 & $0.015^{*}$ & -1.49 & -0.10 \\
\hline & & & & & & & \\
\hline & Homemakers & White-collar workers & 0.681 & 0.201 & $0.005^{* *}$ & 0.15 & 1.21 \\
\hline \multirow{3}{*}{$\begin{array}{l}\text { Worries over buildings collapsing } \\
\text { (preearthquake) } \\
\text { Hochberg test }\end{array}$} & Students & Homemakers & -0.909 & 0.277 & $0.007^{* *}$ & -1.64 & -0.18 \\
\hline & Homemakers & White-collar workers & 0.667 & 0.212 & $0.010^{*}$ & 0.11 & 1.23 \\
\hline & Homemakers & Blue-collar workers & 0.586 & 0.209 & $0.032 *$ & 0.03 & 1.14 \\
\hline \multirow{4}{*}{$\begin{array}{l}\text { Fear of earthquakes } \\
\text { (postearthquake) } \\
\text { Games-Howell test }\end{array}$} & Students & Homemakers & -1.574 & 0.253 & $0.000^{* * *^{\mathrm{a}}}$ & -2.24 & -0.90 \\
\hline & Students & White-collar workers & -0.693 & 0.254 & $0.041^{*}$ & -1.37 & -0.02 \\
\hline & Homemakers & White-collar workers & 0.882 & 0.177 & $0.000^{* * * *^{\mathrm{b}}}$ & 0.42 & 1.34 \\
\hline & Homemakers & Blue-collar workers & 0.983 & 0.171 & $0.000^{* * *^{\mathrm{a}}}$ & 0.54 & 1.43 \\
\hline $\begin{array}{l}\text { Worries over buildings collapsing } \\
\text { (postearthquake) } \\
\text { Games-Howell test }\end{array}$ & Students & Homemakers & -0.982 & 0.285 & $0.005^{* *}$ & -1.73 & -0.24 \\
\hline $\begin{array}{l}\text { Willingness to retrofit houses } \\
\text { (postearthquake) } \\
\text { Hochberg test }\end{array}$ & White-collar workers & Blue-collar workers & 0.499 & 0.156 & $0.009^{* *}$ & 0.09 & 0.91 \\
\hline $\begin{array}{l}\text { Willingness to retrofit houses after professional } \\
\text { assessment } \\
\text { (postearthquake) } \\
\text { Hochberg test }\end{array}$ & White-collar workers & Blue-collar workers & 0.323 & 0.115 & $0.027^{*}$ & 0.03 & 0.62 \\
\hline
\end{tabular}

Table 9. $p$ values and means for house ownership.

\begin{tabular}{|c|c|c|c|c|c|c|}
\hline \multirow[t]{2}{*}{ Items } & \multicolumn{6}{|c|}{ Preearthquake } \\
\hline & Self-owned & Family-owned & Renting & DF & $F$ & $p$ value \\
\hline $\begin{array}{l}\text { Probability of an earthquake disaster occurring } \\
\text { within the next } 10 \text { years }\end{array}$ & 4.02 & 4.09 & 3.98 & 427 & 0.317 & 0.728 \\
\hline Fear of earthquakes & 5.05 & 4.89 & 4.74 & 427 & 2.087 & 0.125 \\
\hline Worries over buildings collapsing & 4.64 & 4.65 & 4.46 & 427 & 0.642 & 0.527 \\
\hline Willingness to retrofit houses & 6.25 & 6.43 & 6.44 & 427 & 0.806 & 0.447 \\
\hline Willingness to retrofit houses after assessment & 6.75 & 6.57 & 6.66 & 427 & 1.248 & 0.288 \\
\hline \multirow[t]{2}{*}{ Items } & \multicolumn{6}{|c|}{ Postearthquake } \\
\hline & Self-owned & Family-owned & Renting & DF & $F$ & $p$ value \\
\hline $\begin{array}{l}\text { Probability of an earthquake disaster occurring } \\
\text { within the next } 10 \text { years }\end{array}$ & 4.61 & 4.74 & 4.32 & 469 & 1.254 & 0.286 \\
\hline Fear of earthquakes & 5.21 & 5.34 & 4.84 & 469 & 0.929 & 0.396 \\
\hline Worries over buildings collapsing & 4.83 & 4.93 & 4.16 & 469 & 1.727 & 0.179 \\
\hline Willingness to retrofit houses & 4.03 & 4.45 & 4.47 & 469 & 4.720 & $0.009 * *$ \\
\hline Willingness to retrofit houses after assessment & 5.47 & 5.55 & 5.63 & 469 & 0.410 & 0.664 \\
\hline
\end{tabular}

${ }^{*} p<0.05 .{ }^{* *} p<0.01 .{ }^{* * *} p<0.001$. 
Table 10. Post hoc results for house ownership (for the categories compared across the two house ownership columns.

\begin{tabular}{lllrrrr}
\hline Items & House & House & Mean & SE & Sig. & 95\% confidence interval \\
\cline { 3 - 7 } & ownership 1 & ownership 2 & difference & & Lower bound & Upper bound \\
\hline $\begin{array}{l}\text { Willingness to retrofit houses } \\
\text { (postearthquake) }\end{array}$ & Self-owned & Family-owned & -0.424 & 0.144 & $0.014^{*}$ & -0.78 \\
Hochberg test & Family-owned & Self-owned & 0.424 & 0.144 & $0.014^{*}$ & 0.07 \\
\hline
\end{tabular}

${ }^{*} p<0.05 .{ }^{* *} p<0.01 .{ }^{* * *} p<0.001$.

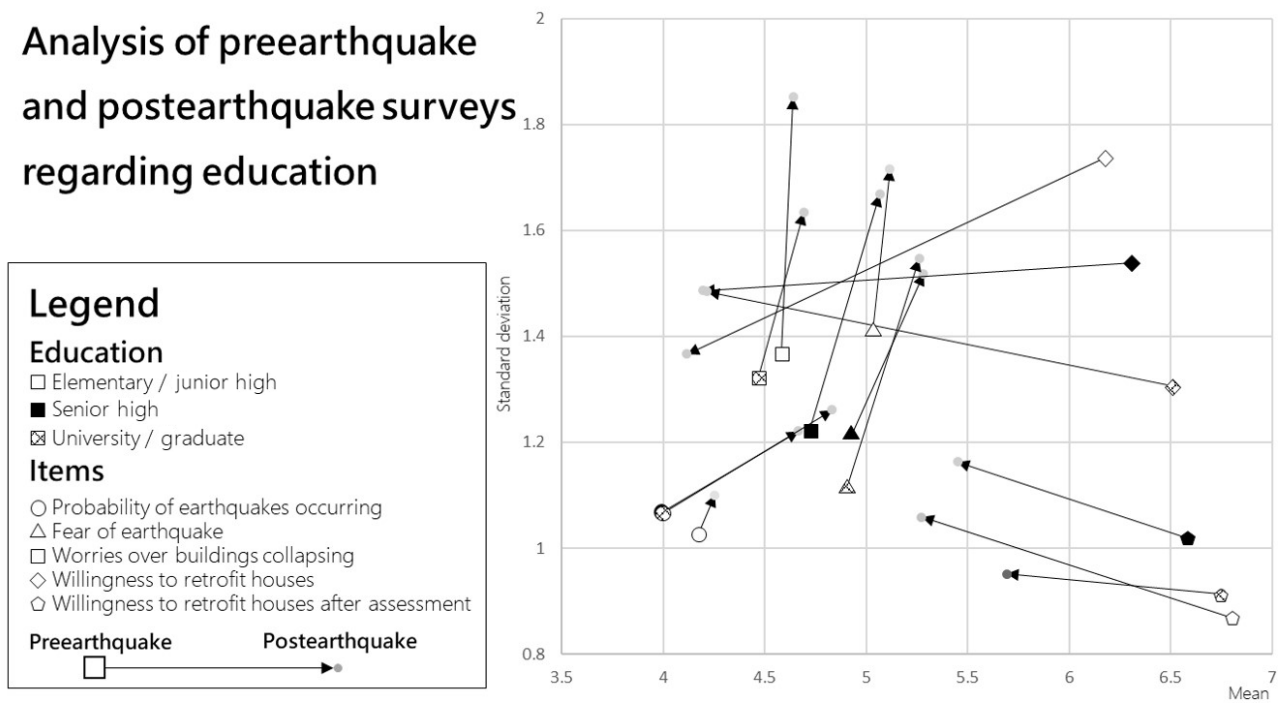

Figure 4. Comparative analysis of the pre- and postearthquake surveys regarding education.

nouncing disaster information, and potential options to respond (Fothergill and Peek, 2004).

Gender, age, and class alone do not make people vulnerable, while the interactions between factors might result in an increase in vulnerability. Overall, social characteristics do indeed affect decisions regarding disaster awareness and adaptation behaviors. In addition, disaster experience does indeed facilitate local awareness but constrains preparedness in regard to Taiwan's earthquake experience. Among gender, education, and occupation, each category shows a similar tendency of increased awareness of risk but decreased willingness to retrofit houses. However, over time, risk awareness might fade away. Therefore, communication, risk education, and diverse mitigation options are required as soon as possible after serious earthquakes to help people be ready for future events.

\section{Conclusions}

Our comparative analysis of predisaster and postdisaster surveys based on various socioeconomic characteristics contributes to the significant and meaningful results of this study. The study found that the responses to earthquake disasters varied between males and females which is consistent with past findings. Although disaster experience does indeed play an important role in helping people become aware of earthquake risk, disaster experience does not necessarily increase people's willingness to retrofit their houses. In addition, people with a higher education and high-salary occupations represent those who might have more available resources, and therefore they might become more willing to prepare for and respond to disasters. Although gender, age, and class alone do not make people vulnerable, the interaction between various socioeconomic characteristics might result in an increase in vulnerability to disasters.

This study explores the changes in risk perceptions and adaptation behaviors based on various socioeconomic characteristics before and after earthquake disasters. However, there are multiple limitations faced in this study. The predisaster survey was a street survey, while the postdisaster survey was a telephone survey based on phone number databases within the study area. Although the questions were the same in the two surveys, the interviewees in the preand postearthquake surveys were different. In addition, the Meinong earthquake was a magnitude 6.6 earthquake which caused one building to fully collapse. Such disaster experi- 

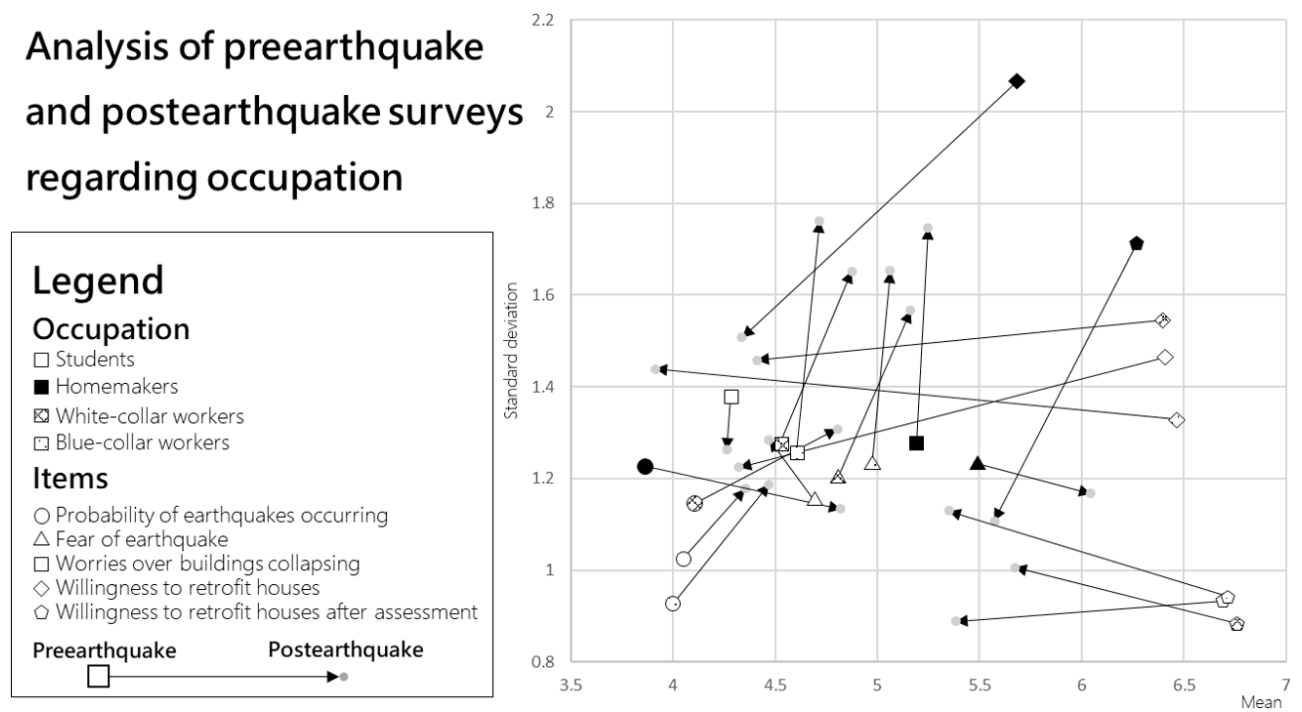

Figure 5. Comparative analysis of the pre- and postearthquake surveys regarding occupation.

ence might not necessary increase awareness of buildings' antiseismic effects. The results might not be applicable to any other disaster events, only earthquakes.

To sum up, the results can provide a general tendency regarding changes in risk perceptions and adaptation behaviors pre- and postdisaster events and the variations between different socioeconomic characteristics based upon Taiwanese disaster experience. The findings can serve as a reference to formulate risk communication strategies and for governments to make decisions on the prioritization of risk management policies. However, there are potential topics that could be extended in future studies, such as the correlation between socioeconomic characteristics and the causes of risk perceptions and their effects on adaptation behaviors.

Data availability. The data will be made available upon request.

Author contributions. TLC and TYC conceived of the presented idea. TLC and HTC developed the conceptual model. TLC performed the computations. TYC encouraged TLC to investigate the comparative analysis of disaster perception pre- and postearthquake disaster and supervised the findings of this work. All authors provided critical feedback and helped shape the research, analysis, and manuscript.

Competing interests. The authors declare that they have no conflict of interest.

Financial support. This research has been supported by the Ministry of Science and Technology of the ROC (grant no. MOST 1032815-C-006-043-H).
Review statement. This paper was edited by Amy Donovan and reviewed by three anonymous referees.

\section{References}

Adger, W. N.: Social and ecological resilience: are they related?, Prog. Hum. Geog., 24, 347-364, https://doi.org/10.1191/030913200701540465, 2000.

Adger, W. N., Dessai, S., Goulden, M., Hulme, M., Lorenzoni, I., Nelson, D. R., and Wreford, A.: Are there social limits to adaptation to climate change?, Climate Change, 93, 335-354, https://doi.org/10.1007/s10584-008-9520-z, 2009.

Always, J., Belgrave, L. L., and Smith, K.: Back to normal: gender and disaster, Symb. Interact., 21, 175-195, https://doi.org/10.1525/si.1998.21.2.175, 1998.

Baker, L. R., and Cornier, L. A.: Disasters and vulnerable populations: Evidence-based practice for the helping professions, Springer Publishing Company, available at: https://psycnet.apa. org/record/2014-08039-000 (last access: 8 September 2020), 2015.

Bankoff, G.: The tale of the three pigs: taking another look at vulnerability in light of the Indian Ocean Tsunami and Hurricane Katrina, Ssrc. Org, available at: https://items.ssrc.org/understanding-katrina/the-tale-of-thethree-pigs-taking-another-look-at-vulnerability-in-the-light-ofthe-indian-ocean-tsunami-and-hurricane-katrina/ (last access: 5 August 2020), 2006.

Barron, G. and Leider, S.: The role of experience in the Gambler's Fallacy, J. Behav. Decis. Making, 23, 117-129, 2010.

Barrows, H. H.: Geography as human ecology, Ann. Assoc. Am. Geogr., 13, 1-14, https://doi.org/10.1080/00045602309356882, 1923.

Becker, J. S., Paton, D., Johnston, D. M., Ronan, K. R., and McClure, J.: The role of prior experience in informing and motivating earthquake preparedness, Int. J. Disast. Risk Re., 22, 179193, https://doi.org/10.1016/j.ijdrr.2017.03.006, 2017 
Bewick, V., Cheek, L., and Ball, J.: Statistics review 9: One-way analysis of variance, Crit. Care, 8, 130-136, https://doi.org/10.1186/cc2836, 2004.

Blake, D., Marlowe, J., and Johnston, D.: Get prepared: discourse for the privileged?, Int. J. Disast. Risk Re., 25, 283-288, https://doi.org/10.1016/j.ijdrr.2017.09.012, 2017.

Blanchard-Boehm, R. D. and Cook, M. K.: Risk communication and public education in Edmonton, Aiberta, Canada on the 10th anniversary of the "Black Friday" Tornado, International Research in Geographical and Environmental Education, 13, 38-54, 2004.

Bostrom, A.: Lead is like mercury: risk comparisons, analogies and mental models, J. Risk Res., 11, 99-117, 2008.

Brown, K. and Westaway, E.: Agency, capacity, and resilience to environmental change: lessons from human development, wellbeing, and disasters. Annu. Rev. Env. Resour., 36, 321-342, https://doi.org/10.1146/annurev-environ-052610-092905, 2011.

Chen, Y. G. and Liu, T. K.: Holocene uplift and subsidence along an active tectonic margin southwestern Taiwan, Quaternary Sci. Rev., 19, 923-930, https://doi.org/10.1016/S02773791(99)00076-1, 2000.

Eagly, A. H. and Chaiken, S.: The Psychology of Attitudes, Harcourt, Brace \& Janovich, Fort Worth, TX, 1993.

Ejeta, L. T., Ardalan, A., and Paton, D.: Application of behavioral theories to disaster and emergency health preparedness: a systematic review, PLoS Curr. Disasters, 1, https://doi.org/10.1371/currents.dis.31a8995ced321301466db,400f 2015.

Enarson, E.: What women do: gendered labor in the Red River valley flood, Environ. Hazards, 3, 1-18, https://doi.org/10.3763/ehaz.2001.0301, 2001.

Erikson, K.: A new species of trouble: the human experience of 40 modern disasters, New York, W. W. Norton, New York, 1994.

Finucane, M., Slovic, P., Mertz, C. K., Flynn, J., and Satterfield, T.: Gender, race, and perceived risk: the "white male" effect, Health. Risk Soc., 2, 159-172, https://doi.org/10.1080/713670162, 2000.

Fordham, M.: Making women visible in disasters: problematizing the private domain, Disasters 22, 126-143, available at: https:// www.ncbi.nlm.nih.gov/pubmed/9654812 (last access: 8 September 2020), 1998.

Fothergill, A. and Peek, L. A.: Poverty and disasters in the U. S.: a review of the recent sociological findings, Nat. Hazards, 32, 295321, https://doi.org/10.1023/B:NHAZ.0000026792.76181.d9, 2004.

Gifford, R.: Environmental psychology: principles and practice, 5th ed., Optimal Books, Colville, WA, 2014.

Heller, K., Alexander, D. B., Gatz, M., Knight, B. G., and Rose, T.: Social and personal factors as predictors of earthquake preparation: the role of support provision, network discussion, negative affect, age, and education, J. Appl. Soc. Psychol., 35, 399-422, 2005.

Huang, M. H., Hu, J. C., Ching, K. E., Rau, R. J., Hsieh, C. S., Pathier, E., Fruneau, B., and Deffontaines, B.: Active deformation of Tainan tableland of southwestern Taiwan based on geodetic measurements and SAR interferometry, Tectonophysics, 466, 322-334, https://doi.org/10.1016/j.tecto.2007.11.020, 2009.

Jones, L. and Tanner, T.: "Subjective resilience": using perceptions to quantify household resilience to climate extremes and disasters, Reg. Environ. Change., 17, 229-243, 2017.
Kerr, J., Nathan, S., Van Dissen, R. J., Webb, P., Brunsdon, D., and King, A. B.: Planning for development of land, on or close to active faults: an interim guideline to assist resource management planners, New Zealand GNS Client Report, Lower Hutt, 2003.

Levine, S.: Assessing resilience: why quantification misses the point, Overseas Development Institute, London, 2014.

Lin, C. W., Chang, H. C., Lu, S. T., Shih, T. S., and Huang, W. J.: An introduction of the active faults of Taiwan, Spec. Publ. Cent. Geol. Surv, 13, 2185-2203, 2000.

Lindell, M. K. and Perry, R. W.: Household adjustment to earthquake hazard: a review of research, Environ. Behav., 32, 461501, https://doi.org/10.1177/00139160021972621, 2000.

Lindell, M. K. and Perry, R. W.: The protective action decision model: theoretical modifications and additional evidence, Risk Anal., 32, 616-632, 2011.

Lindell, M. K., Prater, C. S., Wu, H. C., Huang, S. K., Johnston, D. M., Becker, J. S., and Shiroshita, H.: Immediate behavioural responses to earthquakes in Christchurch, New Zealand, and Hitachi, Japan, Disasters, 40, 85-111, https://doi.org/10.1111/disa.12133, 2016.

Litt, J., Skinner, A., and Robinson, K.: The Katrina difference: African-American women's networks and poverty in New Orleans after Katrina, in: The Women of Katrina: How Gender, Race, and Class Matter in An American Disaster, edited by: David, E. and Enarson, E., 2012.

Luft, R. E.: Looking for common ground: relief work in post1357829 trina New Orleans as an American parable of race and gender violence, NWSA Journal, 20, 5-31, https://www.jstor.org/stable/ 40071294 (last access: 8 September 2020), 2008.

National Applied Research Laboratories: Earthquake Report of Hualien in 2018.02.06, available at: https://www.ncree.org/ EarthquakeInfo/20180206/HualianEqTW_V7.2.pdf (last access: 5 February 2019), 2018.

Nguyen, L. H., Shen, H. K., Ershoff, D., Afifi, A. A., and Bourque, L. B.: Exploring the causal relationship between exposure to the 1994 Northridge earthquake and pre- and post-earthquake preparedness activities, Earthq. Spectra, 22, 569-587, 2006.

Oddsdottir, F., Lucas, B., and Combaz, E.: Measuring disaster resilience. GSDRC Helpdesk Research Report 104, GSDRC, University of Birmingham, UK, 2013.

Paton, D. and Johnston, D. M.: A means-end chain theory analysis of hazard cognitions and preparedness, GNS Science report 2008/19, GNS Science, Lower Hutt, 2008.

Paton, D. and McClure, J.: Preparing for disaster: building household and community capacity, Charles C Thomas Publisher, Springfield, IL, 2013.

Paton, D., Johnston, D., Mamula-Seadon, L., and Kenny, C. M.: Recovery and development: perspectives from New Zealand and Australia, in: Disaster and Development: Examining Global Issues and Cases, edited by: Kapucu, N. and Liou, K. T., Springer, New York, NY, 2014.

Peacock, W. G.: Hurricane mitigation status and factors influencing mitigation status among Florida's single-family homeowners, Nat. Hazards Rev., 4, 149, https://doi.org/10.1061/(ASCE)15276988(2003)4:3(149), 2003.

Peacock, W. G., Brody, S. D., and Highfield, W. E.: Hurricane risk perceptions among Florida's single family homeowners, Landscape Urban Plan., 73, 120-135, https://doi.org/10.1016/j.landurbplan.2004.11.004, 2005. 
Perry, R. W. and Lindell, M. K.: Volcanic risk perception and adjustment in a multi-hazard environment, J. Volcanol. Geoth. Res., 172, 170-178, 2008.

Petak, W. J. and Atkisson, A. A.: Natural hazard risk assessment and public policy: anticipating the unexpected, Springer-Verlag, New York, 1982.

Rüstemli, A. and Karanci, A. N.: Correlates of earthquake cognitions and preparedness behavior in a victimized population, J. Soc. Psychol., 139, 91-101, 1999.

Sheaffer, J. R. and Roland, F. J.: Flood Hazard Mitigation through Safe Land Use and Construction Practices, Keifer \& Associates, Inc., Chicago, 1976.

Sjöberg, L.: A discussion of the limitations of the psychometric and cultural theory approaches to risk perception, Radiat. Prot. Dosim., 68, 219-225, https://doi.org/10.1093/oxfordjournals.rpd.a031868, 1996.

Sjöberg, L.: Factors in risk perception, Risk Anal., 20, 1-12, https://doi.org/10.1111/0272-4332.00001, 2000.

Solberg, C., Rossetto, T., and Joffe, H.: The social psychology of seismic hazard adjustment: re-evaluating the international literature, Nat. Hazards Earth Syst. Sci., 10, 1663-1677, https://doi.org/10.5194/nhess-10-1663-2010, 2010.

Tobin-Gurley, J. and Enarson,: Social Vulnerability to Disasters, 2nd Edition, CRC Press, Florida, US, 2013.

Tsai, C. C., Hsu, S. Y., Wang, K. L., Yang, H. C., Chang, W. K., Chen, C. H., and Hwang, Y. W.: Geotechnical reconnaissance of the 2016 ML 6.6 Meinong Earthquake in Taiwan, J. Earthquake Eng., 22, 1-27, https://doi.org/10.1080/13632469.2017.1297271, 2017.
Turner, R. H., Nigg, J. M., and Paz, D. H.: Waiting for disaster: earthquake watch in California, University of California Press, Berkeley, 1986.

UNDRR: Sendai Framework for Disaster Risk Reduction 2015-2030, United Nations, available at: https://www.undrr.org/publication/ sendai-framework-disaster-risk-reduction-2015-2030 (last access: 8 September 2020), 2015.

UNISDR: International Decade for Natural Disaster Reduction (IDNDR) programme forum 1999 - proceedings, available at: https://www.unisdr.org/we/inform/publications/31468, last access: 23 March 2019.

USGS (U.S. Geological Survey): Ring of Fire, available at: https: //earthquake.usgs.gov/learn/glossary/?termID=150, last access: 2 November 2017.

Whitely, E. and Ball, J.: Statistics review 5: Comparison of means, Crit. Care., 6, 424-428, https://www.ncbi.nlm.nih.gov/ pmc/articles/PMC137324/ (last access: 8 September 2020), 2002.

Whitney, D. J., Lindell, M. K., and Nguyen, H. D., earthquake beliefs and adoption of seismic hazard adjustments, Risk Anal., 24, 87-102, 2004.

Wisner, B., Blaikie, P., Cannon, T., and Davis, I.: At Risk: Natural Hazards, People's Vulnerability and Disasters, Routledge, London, 2004.

Wu, J. Y. and Lindell, M. K. Housing reconstruction after two major earthquakes: the 1994 Northridge earthquake in the United States and the 1999 Chi-Chi earthquake in Taiwan, Disasters, 28, 6381, https://doi.org/10.1111/j.0361-3666.2004.00243.x, 2004. 